\title{
Silvotehnica molidișurilor artificiale, pure și tinere, din România: un exemplu
}

\author{
V.-N. Nicolescu, A. Pătrăucean, D.-C. Șimon, M.-N. Ciolan, F.-L. Alexandrescu, E. Balcanu
}

Nicolescu, V.-N., Pătrăucean, A., Șimon, D.-C., Ciolan, M.-N., Alexandrescu, F.-L., Balcanu, E. 2020. Silviculture of artificial, pure and young Norway spruce stands: an example. Bucov. For. 20(1):7-21

Abstract. The paper shows the results of a small-scale R\&D project on early silviculture of Norway spruce, carried out in a pure plantation of 0.4 ha, 2 x $1 \mathrm{~m}(5,000$ plants $\mathrm{ha}^{-1}$ ), established in 2001. In 2009, following the application of an access pruning on all stand trees, 60 "potential" final crop trees were selected throughout the stand, based on the vigour-quality-distribution criteria, being subsequently pruned up to $4-4.5 \mathrm{~m}$. In the same year, two plots, each of 300 sq.m, were established and a mixed and heavy cleaning-respacing was carried out classically (typical to stand silviculture, in plot 1) or dynamically (as in case of crop tree silviculture, in plot 2). A classical cleaning-respacing (mean canopy cover $80 \%$ after intervention) was also performed at stand level, leaving the "potential" final crop trees in a free-growth state at the crown level. A mixed thinning, similar to the intervention in 2009, was carried out at both plot and stand level in 2013, with the remaining density of 1,167 trees ha $^{-1}$ (plot 2) and 1,567 trees ha ${ }^{-1}$ (plot 1) and basal area of 20.67 sq.m ha-1 (plot 2) and 23.47 sq. $\mathrm{m} \mathrm{ha}^{-1}$ (plot 1). In 2020, the mean arithmetic diameter and mean quadratic diameter of trees in plot 2 and "potential" final crop trees reached $20 \mathrm{~cm}$. Out of these trees, over $50 \%$ are at least $20 \mathrm{~cm}$ in diameter. The basal area in plots 1 and 2 is over 35 sq. $\mathrm{m} \mathrm{ha}^{-1}$ so a new thinning is due to be carried out in 2020, to reduce the basal area under the critical value of 30 sq. $\mathrm{m} \mathrm{ha}^{-1}$. Mean height reached $15 \mathrm{~m}$ in 2020, and the slenderness (stability) index has grown significantly only in plot 1 , reaching the value of 85 . The R\&D project showed clearly the possibility of producing Norway spruce trees of $20 \mathrm{~cm} \mathrm{d.b.h.} \mathrm{in}$ 20 years, by using intensive crop tree silviculture started earlier, during the thicket development stage.

Keywords Norway spruce, cleaning-respacing, thinning, crop tree silviculture, diameter increment.

Authors. Valeriu-Norocel Nicolescu (nvnicolescu@unitbv.ro), Florentina-Loredana Alexandrescu, Elena Balcanu - Transilvania University of Brașov, Faculty of Silviculture and Forest Engineering, Sirul Beethoven, no. 1, 500123 - Brașov, Romania; Aurica Pătrăucean - Ocolul Silvic Lignum, Str. Energiei, nr. 415, 605300 Dărmănești, jud. Bacău, România; Diana-Cristina Șimon - Master's Degree Programme in European Forestry, University of Eastern Finland, Joensuu, Finland; Matei-Nicolae Ciolan - Ocolul Silvic Privat Oituz S.R.L., str. Principală, nr. 198, 607365 Oituz, jud. Bacău, România.

Manuscript received March 27, 2020; revised April 27, 2020; accepted April 30, 2020; online first July 20, 2020. 


\section{Introducere}

Molidul (Picea abies (L.) Karst) este una dintre cele mai importante specii de rășinoase din spațiul european, cu un rol ecologic major în arborete pure sau de amestec alături de brad și fag din regiunile muntoase ale continentului. Specia are și o importanță economică majoră, prin cultura sa ușoară, rapiditatea de creștere, producția ridicată și ciclurile de producție în general scurte, fiind considerată, de multă vreme, în diverse țări europene gen Germania, Franța, Belgia, Austria, Marea Britanie, Cehia, drept un arbore-pâine (Schmidt-Vogt 1967, în Marcu 1974).

Din păcate, folosirea molidului pe scară largă, începând din secolul al 19-lea, ca ,,prima specie de împădurire din Europa" (RiouNivert 1996), a condus la apariţia în timp a numeroase probleme în molidişuri, unele catastrofale, datorate vântului, zăpezii, secetei estivale (Caudullo et al. 2016).

La acestea s-au adăugat, în ultimii ani, vătămările datorate gradațiilor puternice ale gândacilor de scoarță, atât în Scandinavia, cât și în țări precum Germania, Franța și, mai ales, Cehia, unde milioane de $\mathrm{m}^{3}$ de lemn de molid au fost infestate de ipide pe fondul secetei extreme (https://madeira.fordaq.com/news/ France_spruce_bark_beetle_64805.html, Duduman și Lupaștean 2019).

În plus, molidișurile europene se estimează că vor fi afectate semnificativ de schimbările climatice viitoare, ceea ce a condus la căutarea unor alternative la cultura molidului, așa cum sunt instalarea speciei numai în arborete amestecate și nu în monoculturi sau chiar substituirea molidului cu bradul (Abies alba Mill.), folosind proveniențe mediteraneene sau din zone mai uscate ale Alpilor (Caudullo et al. 2016), ori cu duglasul verde (Pseudotsuga menziesii (Mirbel) Franco), specie considerată mai adaptată la schimbările climatice așteptate în Germania (Pukall 2019) sau Cehia (Zeidler şi Borůvka 2018, van Loo și Dobrowolska 2019).

Diversele probleme ale culturilor de mo- lid, mai ales de stabilitate la acţiunea zăpezii și a vântului, sunt în legătură cu numărul de puieți ha ${ }^{-1}$ la instalare, respectiv cu silvotehnica aplicată arboretelor tinere. Astfel, tendința evidentă a ultimelor decenii din secolul trecut, respectiv a începutului de secol 21 , pentru mărirea stabilităţii culturilor, dar și pentru reducerea costurilor de instalare și cu forța de muncă, este de micșorare a densității inițiale a plantațiilor de molid. Dacă, la începutul secolului trecut, aceasta atingea sau chiar depășea 10000 puieți ha ${ }^{-1}$, în prezent nu mai

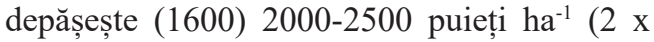
2 m, $2 \times 2,5$ m, chiar 2,5 x 2,5 m) în țări ca Germania (Mäkinen şi Hein 2006, Vor com. pers.), Austria (Weinfurter 2004), Belgia (BaryLenger et al. 1988, Hébert et al. 2002, Perin 2016), Franța (Tisserand şi Pardé 1982, Pardé 1984, Changsheng et al. 1998), Croația (Orlić 1989), Irlanda (Anonymous 2009), Marea Britanie (Hart 1994, Savill et al. 1997), Lituania (Zeltiņš 2017, Katrevičs et al. 2018), Italia (La Porta com.pers), Slovenia (Brus com.pers), Bosnia și Herzegovina (Cvjetkovic com.pers.), Macedonia de Nord (Mandzukovski com.pers). Astfel de recomandări există și în literatura silvică românească (de exemplu, Barbu 1982 - a se folosi molidul, în stațiuni afectate de doborâturi de zăpadă, la 2 x 2 m sau 2,5 x 2,5 m, respectiv cu 1600-2500 puieți ha-1 ${ }^{-1}$ ), de care însă nu s-a ținut cont la elaborarea îndrumărilor și normelor tehnice pentru împăduriri din anii 1987 și 2000. În același context, este interesant de remarcat faptul că, în urmă cu aproape 100 de ani, profesorul Marin Drăcea recomanda ca molidul să se planteze, ,în pământuri foarte bune", la 1,75 x 1,75 m (3265 puieți ha $\left.{ }^{-1}\right)$ (Drăcea 1923).

Dacă plantarea se face cu densități inițiale mai mari, de până la 4000-5000 (chiar 6000) puieți ha ${ }^{-1}$ (cazul României: Anonymous 2000a; Ungariei: Rédei com.pers.; Bulgariei: Petkova com.pers.; Poloniei: Klisz com. pers.; Cehiei: Podrázský com.pers.; Ucrainei: Lavnyy com.pers.), se recomandă aplicarea de curăţiri timpurii (la finele stadiului de nuieliș) și forte, în scopul producerii de arbori cu co- 
eficienți de zveltețe $\left(\mathrm{I}_{\mathrm{z}}\right)$ sub 75-80, cu coroane mari și simetrice, stabili la acțiunea zăpezii sau a vântului (Petrescu et al. 1962, Petrescu et al. 1967, Petrescu și Haring 1977, Kramer 1980, Barbu 1982, Tisserand și Pardé 1982, Savill et al. 1983, Becquey și Riou-Nivert 1987, Scohy 1989, Szymański 2007).

Alte aspecte importante pentru conducerea arboretelor de molid cu rol de producție de lemn sunt (i) diametrul-țel la vârsta exploatabilităţii, respectiv (ii) lățimea inelelor de creștere (anuale), cerute de către utilizatorii buștenilor de molid ori impuse prin standarde/norme europene sau naţionale. Astfel, tendința la nivelul unor țări europene (de exemplu, Franța, Germania, Italia, Polonia, Ungaria, Macedonia de Nord) este de reducere a diametrului-țel pentru sortimentul ,buștean de gater” la valori care nu depășesc $50 \mathrm{~cm}$ (de preferat 40-45 $\mathrm{cm}$ ), din rațiuni de manipulare în parchetele de exploatare, pe platformele primare sau în fabricile de cherestea (Pain 1996, Bastien 1997, 2000, Buculei com.pers., Mandzukovski com. pers., La Porta com.pers., Rédei com.pers., Vor com.pers.). În acest context, este demn de reținut faptul că, într-o panoramă a industriei europene de prelucrare a lemnului (Bary-Lenger et al. 1999), s-a subliniat faptul că buștenii (cu lungimea de $2-4,5$, chiar $5 \mathrm{~m}$ ) utilizați în fabricile de cherestea cu caracter industrial (care prelucrau volume lemnoase de minim zeci de mii de $\mathrm{m}^{3}$ pe an) trebuie să nu depășească 30 cm în diametru la capătul subțire.

Recomandarea ca diametrul-țel al arborilor de molid de prelucrat în cherestea să nu depăşească $50 \mathrm{~cm}$ este în consonanță cu diametrul-țel al speciei în arborete regenerate pe cale naturală și parcurse cu tăieri grădinărite, unde atinge 45-50 (55, rareori 60) cm în țări ca Elveția (Borel 1929), Franța (Perrin 1954, Cochet 1971), Slovacia (Saniga 2007) etc.

Lemnul cel mai căutat în buștenii de molid pentru gater este cel cu creșteri radiale de 3-4 $\mathrm{mm} \mathrm{an}^{-1}$ (clasa A în standardele din Franța Baylot și Vautherin 1991, Pain 1996, AFNOR 1999; Italia - Pollini 2006; Germania - Vor com.pers.; România - Buculei com.pers.), ur- mat de cel cu inele de creștere de 5-6 (7) mm lățime (clasa B). În acest sens, trebuie menționat faptul că mărirea lăţimii inelului de creştere la rășinoase nu afectează nici densitatea inițială a lemnului timpuriu (format din traheide cu pereți subțiri), nici lăţimea lemnului târziu (traheide cu pereți groși), această mărire concentrându-se aproape integral asupra lățimii lemnului de primăvară (Horodnic 1999). Datorită acestui fenomen, densitatea lemnului scade, acesta fiind mai „ușor” (spre exemplu, de la $435 \mathrm{~kg} \mathrm{~m}^{-3}$ la arborii cu creștere lentă/ inele înguste la $403 \mathrm{~kg} \mathrm{~m}^{-3}$ la cei cu creștere rapidă/inele late - Hébert et al 2002), și se formează lemn de compresiune, cu proprietăți fizico-mecanice mai slabe (Beldeanu 1999, 2008; Hébert et al 2002). În schimb, arborii cu creștere radială mai accentuată/inele mai late prezintă stabilitate dimensională mai bună, datorită contragerii mai reduse (DumitriuTătăranu et al. 1983, Hébert et al 2002).

Faptul că se produce lemn de molid cu inele de creștere mai late nu constituie însă o problemă pentru producția de cherestea (scânduri, dulapi, grinzi etc), deoarece aceasta „nu necesită în general rezistențe mecanice mari, deci nici densitate ridicată" (Dumitriu-Tătăranu et al. 1983). După aceeași specialiști români reputați, ,... la lemnul de rășinoase (pentru producția de cherestea - n.n.) nu este necesară o proporție ridicată de lemn târziu și, deci, creșterea rapidă a arborilor cu inele late nu constituie un dezavantaj”. Același lemn cu densitate mai redusă este considerat cel mai corespunzător și pentru producerea de plăci din așchii de lemn aglomerate $(,, \ldots$ densitatea lemnului determină densitatea plăcilor, iar rezistența la încovoiere a plăcilor este cu atât mai mare cu cât lemnul este mai uşor"), ca şi pentru cea de placaj și alte stratificate din furnire $(, \ldots$ lemnul convenabil este cel cu... inele de creștere late la răşinoase, ... cu densitate și contragere reduse") (Dumitriu-Tătăranu et al. 1983).

Deoarece industria prelucrătoare poate utiliza lemn cu calități fizico-mecanice variate, a fost posibilă producerea unor modele/scenarii silvotehnice (de la instalarea culturilor până la 
exploatabilitate) în funcție de cele două calități (A și B) dorite: pentru obținerea „lemnului cu inele înguste", de 3-4 mm, în bușteni de 50$55 \mathrm{~cm}$ în diametru, respectiv a ,lemnului cu inele late", de 5-6 mm, în bușteni de 40-45 cm (Franța: Pain 1996).

In acest context larg, lucrarea noastră și-a propus să prezinte cele mai importante rezultate ale unei lucrări experimental-demonstrative, cu durata de peste 10 ani (începută în anul 2009), privind silvotehnica arboretelor pure și tinere de molid. O serie de aspecte specifice acesteia au fost prezentate deja în câteva lucrări: Pătrăucean și Nicolescu 2011, Pătrăucean 2012, Faure et al. 2015. Prin această lucrare experimental demonstrativă se încearcă să fie armonizate obiectivul stabilității la acțiunea zăpezii/vântului cu necesitatea obținerii de bușteni de gater la vârste ale exploatabilității mai scurte decât cele impuse prin normele tehnice românești în vigoare (de la 100 de ani la clasa a IV-a de producție la 120 de ani la clasa I - Anonymous 2000c). Aceste vârste ale exploatabilității sunt mai lungi decât cele din unele țări europene, unde nu depășesc, în general, 70-80 de ani (Franța: 50-80 (100) ani - Bastien 1997, 2000; Marea-Britanie: 4975 ani - Hart, 1994; Belgia: 53-83 ani - Perin 2016; Irlanda: 45-60 ani - Anonymous 2009; Lituania: 81 ani - Zeltiņš 2017; Estonia: 80 ani - Läänelaid et al. 2016; Polonia: 80 ani - Klisz com.pers.).

\section{Material și metodă de lucru}

Lucrările de teren pentru realizarea cercetărilor cu caracter demonstrativ s-au realizat în u.a. $112 \mathrm{D}$ (coordonate $45.535170^{\circ} \mathrm{N}$, $25.586204^{\circ} \mathrm{E}$ ), U.P. III Postăvaru, din Regia Publică Locală a Pădurilor Kronstadt (Braşov). Această subparcelă are o suprafață de 0,4 ha, iar principalele caracteristici ale stațiunii de cultură sunt: altitudine medie 840 m, înclinare medie $5^{\mathrm{g}}$, tip de staţiune 3333 Montan de amestecuri Bs, eutricambosol edafic mare, cu Asperula-Dentaria. Climatul este boreal
(Dfck), cu temperatura medie anuală de $6-7^{\circ} \mathrm{C}$ şi 750-800 mm precipitații medii anuale.

Arboretul studiat constă dintr-o plantaţie pură de molid instalată în anul 2001 cu schema de 2 x $1 \mathrm{~m}$ (5.000 puieţi ha-1 ${ }^{-1}$, utilizând puieţi de doi ani produși în pepiniera proprie situată în imediata vecinătate a u.a. 112D. În aprilie 2009, când plantația avea 8 ani, după ce s-a practicat un elagaj de accesibilizare pe maximum 2,5 m înălţime la toți arborii existenți în u.a., au fost selectați şi punctaţi cu vopsea, pe baza criteriilor vigoare (arborii cei mai groşi), calitate (drepți, crescuți vertical, cu ramuri cât mai subţiri şi mai orizontale, coroane mari şi simetrice, fără înfurciri, cancere, răni etc) şi spaţiere (situaţi la distanţe cât mai constante, în general de 4-6 m), 60 de ,potenţiali” arbori de viitor (PADV, 150 exemplare ha-1), care au fost elagați până la 4-4,5 m înălţime.

În arboret s-au instalat apoi două suprafeţe de probă (SP) de câte $300 \mathrm{~m}^{2}(20 \times 15$ m), în care toţi arborii au fost numerotaţi cu vopsea albă şi li s-au stabilit coordonatele x-y. În ambele suprafețe au fost selectaţi pe baza acelorași criterii, pe lângă ,,potenţialiii” arbori de viitor aleși anterior, și alte exemplare, care s-au elagat până la 4-4,5 m înălțime, astfel încât numărul lor a fost de 9 (300 arb ha-1), în SP1, respectiv de 10 (333 arb ha $\left.{ }^{-1}\right)$, în SP2.

Ulterior, în cele două SP s-a aplicat în anul 2009 o lucrare de curăţiri în două variante:

i) SP1: intervenţie clasică, specifică silviculturii de arboret, prin care s-au extras exemplare individuale (arbori înfurciţi, cu răni, din zone prea dese etc), fără a se acorda vreo atenţie specială favorizării ,,potenţialilor” arbori de viitor. În urma intervenţiei, consistenţa arboretului s-a redus relativ uniform, în măsura posibilului, la nivelul mediu de 0,8 .

ii) SP2: intervenţie dinamică, caracteristică pentru silvicultura de arbore, în care curăţirile s-au concentrat în jurul „potenţialilor” arbori de viitor, prin extragerea celor mai importanți competitori ai acestora, cu scopul de a le asigura un regim apropiat de starea de creştere liberă la nivelul coroanei. În urma intervenţiei, nivelul consistenţei s-a redus relativ neuniform, 
atingând nivelul mediu 0,7 , cu o variaţie de la 0,5 (în zonele din jurul arborilor ,potenţial” de viitor) până la 0,9 , în zonele fără ,,potențiali” arbori de viitor.

În plus, în arboretul din jurul celor două SP s-a intervenit cu o curăţire ,clasică” (cu păstrarea unui nivel al consistenţei după lucrare de 0,8), doar în jurul unei părți din cei 60 ,potenţiali" arbori de viitor intervenindu-se similar cu SP2, pentru a le permite acestora evoluţia în condiţii apropiate de starea de „creştere liberă” (figura 1).

În anul 2013, la nivelul întregului arboret, al suprafețelor de probă și al ,potențialilor” arbori de viitor, s-a aplicat a doua intervenție, de această dată de răritură, cu un mod de lucru similar lucrării realizate în 2009 (figura 2).

La arborii din cele două SP, precum şi la cei 60 ,potenţiali” arbori de viitor, s-a procedat la măsurarea următorilor parametri biometrici:

i) diametrul de bază $\left(\mathrm{d}_{1.30}\right)$ (în 04.2009, înainte și după curățire; 05.2010;06.2011; 05.2012; 07.2013, înainte și după răritură; 09.2015; 04.2018 și 03.2020); s-a folosit o clupă Haglöf de $30 \mathrm{~cm}$, cu precizia de $1 \mathrm{~mm}$.

ii) înălțimea totală (h) (în 04.2009, după curățire; 05.2010; 07.2013, după răritură; 04.2018 și 04.2020); a fost utilizată, în anii 2009, 2010 și 2013, o prăjină telescopică de fabricație S.U.A., cu lungimea desfăşurată de $15 \mathrm{~m}$ și precizia de $1 \mathrm{~cm}$, respectiv hipsometrul românesc cu pendul ( + dendometrul Suunto, pentru control), cu precizia de $10 \mathrm{~cm}$, în 2018 şi 2020 .

iii) patru raze ale coroanei $\left(r_{1}, r_{2}, r_{3}\right.$ şi $\left.r_{4}\right)$, dispuse în unghi de $90^{\circ}$ între ele, în 04.2009 (după curățire), 05.2010, 07.2013 (după răritură), 09.2015 și 04.2018 , folosind o ruletă metalică cu lungimea de $5 \mathrm{~m}$ şi precizia de $1 \mathrm{~cm}$. În anul 2020 nu a mai fost posibilă măsurarea razelor coroanei, datorită închiderii complete a coronamentului.

$\mathrm{Cu}$ ajutorul acestor date de teren, în etapa de birou, s-au realizat diverse calcule biometrice folosind aplicaţia Microsoft $\operatorname{Excel}^{(\mathrm{R})}$ : diametre medii aritmetice đ, diametre medii ale suprafeței de bază $d_{g}$, suprafețe de bază

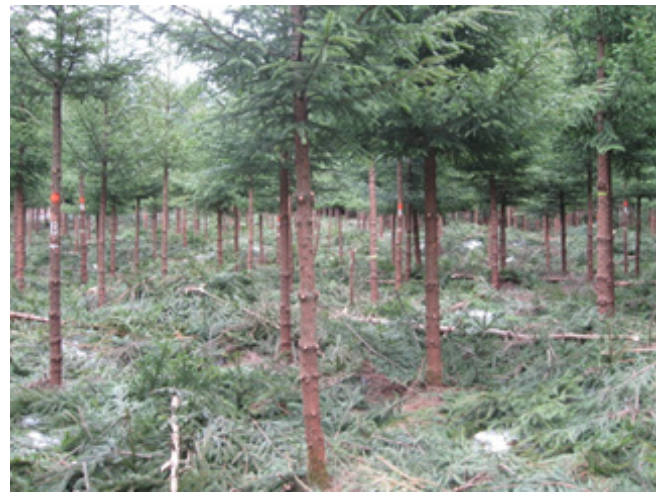

Figura 1 Aspectul arboretului în anul 2009 (vârsta 8 ani), după realizarea lucrărilor de curăţiri şi elagaj artificial, cu arborii ,potenţial” de viitor aleşi şi însemnaţi cu puncte de vopsea Sub-compartment 112D in 2009 (age 8 years) after cleaning-respacing and artificial pruning, with "potential" final crop trees selected and painted

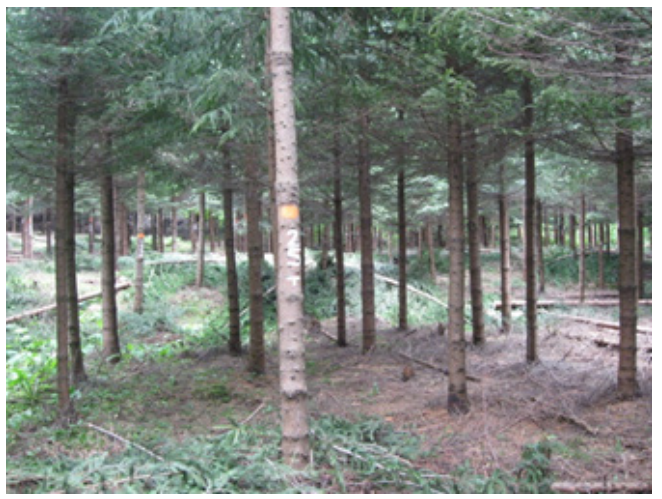

Figura 2 Aspectul arboretului în anul 2013 (vârsta 12 ani), după realizarea lucrării de rărituri, cu „potenţialii”" arbori de viitor aleşi şi însemnaţi cu puncte de vopsea

Sub-compartment 112D in 2013 (age 12 years) after thinning, with "potential" final crop trees selected and painted

G, înălțimi medii aritmetice h, înălțimi corespunzătoare diametrului mediu al suprafeței de bază $h_{g}$, coeficienți de zveltețe medii $I_{z}$, diametre medii ale coroanei dmedcor. Folosind acelaşi soft, au fost stabilite pe cale grafică corelațiile $\mathrm{d}_{1,30 \text {-inițial 2009 }}$ - creștere în diametru 2009-2020 și $\mathrm{d}_{1.30}-\mathrm{d}_{\text {medcor }}$ în diverși ani. 


\section{Rezultate}

\section{Lucrări silvotehnice aplicate}

Lucrările de curățiri aplicate în anul 2009, pornind de la desimi (arb ha-1) şi densități $\left(\mathrm{m}^{2} \mathrm{ha}^{-1}\right)$ ridicate, au fost predominant combinate, $\mathrm{cu}$ accent de jos (intensitatea pe număr de arbori $\mathrm{I}_{\mathrm{N}}$ mai mare decât cea pe suprafață de bază $\mathrm{I}_{\mathrm{G}}$ ) și cu intensități foarte puternice sau puternice în ambele SP. Oricum, intensitatea lucrării a fost mult mai ridicată în SP2, unde au rămas după intervenţie doar $1400 \mathrm{arb}^{-1}$, respectiv 9,85 $\mathrm{m}^{2}$ ha $^{-1}$, comparativ cu 2100 arb ha-1 şi 14,24 $\mathrm{m}^{2}$ ha $^{-1}$ în SP1 (tabelul 1).

Răriturile din anul 2013 au prezentat același caracter de intervenție combinată, însă cu un caracter mai slab de jos și având intensităţi mai reduse atât pe număr de arbori, cât și pe suprafață de bază, fiind însă mai mari în SP1. Desimile rămase după răritură s-au redus la

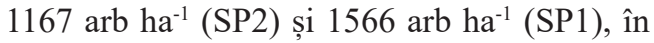
timp ce densitățile rămase au avut niveluri peste $20 \mathrm{~m}^{2}$ ha $^{-1}$ în ambele SP (tabelul 2).

\section{Efectele lucrărilor silvotehnice din 2009 și 2013 asupra câtorva parametri biometrici și statistici ai arborilor din SP și „,potențialilor” arbori de viitor}

Între 2009 şi 2020, diametrul mediu aritmetic đ a crescut cu valori importante, oscilând de la 8,47 cm în SP1 la 11,08 cm la ,potențialii” arbori de viitor, adică o creștere, exprimată în valori relative, de la $91,54 \%$ (SP1) la $115,73 \%$ (PADV), ceea ce presupune dublarea valorilor inţiale din anul 2009 (tabelul 3).

Tabel1 Principalele caracteristici ale curăţirii practicate în SP1 şi SP2 în 2009

Main characteristics of cleaning-respacing carried out in plots 1 and 2 in 2009

\begin{tabular}{|c|c|c|c|c|c|c|c|c|}
\hline \multirow{2}{*}{$\begin{array}{l}\text { SP } \\
\text { nr. }\end{array}$} & \multicolumn{3}{|c|}{ Numărul de arbori (N) la ha } & \multirow{2}{*}{$\begin{array}{c}\mathrm{I}_{\mathrm{N}} \\
(\%)\end{array}$} & \multicolumn{3}{|c|}{ Suprafaţa de bază $(\mathrm{G})$ la ha $\left(\mathrm{m}^{2}\right)$} & \multirow{2}{*}{$\begin{array}{l}I_{G} \\
(\%)\end{array}$} \\
\hline & Iniţ̧ial & Extraşi & Rămaşi & & $\begin{array}{l}\text { Arbori } \\
\text { iniţiali }\end{array}$ & $\begin{array}{l}\text { Arbori } \\
\text { extraşi }\end{array}$ & $\begin{array}{l}\text { Arbori } \\
\text { rămaşi }\end{array}$ & \\
\hline 1 & 2933 & 833 & 2100 & 28,40 & 17,84 & 3,60 & 14,24 & 20,18 \\
\hline 2 & 3000 & 1600 & 1400 & 53,33 & 18,23 & 8,38 & 9,85 & 45,97 \\
\hline
\end{tabular}

Tahel 2 Principalele caracteristici ale răriturii aplicate în SP1 şi SP2 în 2013

Main characteristics of thinning carried out in plots 1 and 2 in 2013

\begin{tabular}{|c|c|c|c|c|c|c|c|c|}
\hline \multirow{2}{*}{$\begin{array}{l}\text { SP } \\
\text { nr. }\end{array}$} & \multicolumn{3}{|c|}{ Numărul de arbori (N) la ha } & \multirow{2}{*}{$\begin{array}{c}\mathrm{I}_{\mathrm{N}} \\
(\%)\end{array}$} & \multicolumn{3}{|c|}{ Suprafaţa de bază $(\mathrm{G})$ la ha $\left(\mathrm{m}^{2}\right)$} & \multirow{2}{*}{$\begin{array}{c}\mathrm{I}_{\mathrm{G}} \\
(\%)\end{array}$} \\
\hline & Iniţial & Extraşi & Rămaşi & & $\begin{array}{l}\text { Arbori } \\
\text { iniţiali }\end{array}$ & $\begin{array}{l}\text { Arbori } \\
\text { extraşi }\end{array}$ & $\begin{array}{l}\text { Arbori } \\
\text { rămaşi }\end{array}$ & \\
\hline 1 & 2033 & 467 & 1566 & 22,97 & 29,04 & 5,57 & 23,47 & 19,18 \\
\hline 2 & 1400 & 233 & 1167 & 16,64 & 23,56 & 3,20 & 20,36 & 13,58 \\
\hline
\end{tabular}

Tahel 3 Dinamica diametrului mediu aritmetic (đ) la arborii din SP1 și SP2 și la „potențialii” arbori de viitor Dynamics of arithmetic mean diameter (d) of trees in plots 1 and 2 and of "potential " final crop trees

\begin{tabular}{|c|c|c|c|c|c|c|c|c|c|}
\hline \multirow{3}{*}{$\begin{array}{l}\text { SP } \\
\text { nr. }\end{array}$} & \multicolumn{6}{|c|}{ Diametrul mediu aritmetic în... $(\mathrm{cm})$} & \multirow{3}{*}{$\begin{array}{c}\text { Variația } \\
\text { creșterii în } \\
\text { diametru la } \\
\text { arborii indi- } \\
\text { viduali }(\mathrm{cm})\end{array}$} & \multirow{3}{*}{$\begin{array}{l}\text { Ponderea } \\
\text { arborilor cu } \\
\text { diametrul } \\
\text { minim } 10 \mathrm{~cm} \\
\text { în } 2009,(\%)\end{array}$} & \multirow{3}{*}{$\begin{array}{c}\text { Ponderea } \\
\text { arborilor cu } \\
\text { diametrul } \\
\text { minim } 20 \mathrm{~cm} \\
\text { în } 2020,(\%)\end{array}$} \\
\hline & \multirow{2}{*}{$\begin{array}{c}09.04 \\
2009\end{array}$} & \multirow{2}{*}{$\begin{array}{c}04.07 . \\
2013 \\
\text { înainte }\end{array}$} & \multirow{2}{*}{$\begin{array}{c}04.07 . \\
2013 \\
\text { după }\end{array}$} & \multirow{2}{*}{$\begin{array}{c}13.03 . \\
2020\end{array}$} & \multicolumn{2}{|c|}{$\begin{array}{c}\text { Creșterea lui đ } \\
\text { între 2009 și } 2020 \\
\end{array}$} & & & \\
\hline & & & & & $(\mathrm{cm})$ & $(\%)$ & & & \\
\hline 1 & 9,25 & 13,30 & 13,49 & 17,72 & 8,47 & 91,54 & $2,3-13,8$ & 30,65 & 23,91 \\
\hline 2 & 9,35 & 14,40 & 14,24 & 19,70 & 10,35 & 110,77 & $2,6-16,4$ & 33,33 & 51,43 \\
\hline PADV & 9,57 & 14,67 & 14,67 & 20,65 & 11,08 & 115,73 & $7,2-14,2$ & 35,00 & 62,71 \\
\hline
\end{tabular}


Diametrul mediu aritmetic al arborilor din SP2 şi al celor din categoria PADV s-a apropiat sau chiar a depăşit valoarea de $20 \mathrm{~cm}$. Ponderea exemplarelor care au atins diametrul de $20 \mathrm{~cm}$ în anul 2020 a depăşit 50\% în ambele situații (tabelul 3), iar arborele cel mai gros și cu creșterea maximă în diametru între 2009 și 2020 se găsește în SP2 (figura 3).

Diametrul mediu al suprafeței de bază d prezintă o dinamică similară lui đ, depășind valoarea de $20 \mathrm{~cm}$ în SP2 şi la PADV, unde cel puțin s-a dublat în perioada 2009-2020 (tabelul 4).

Dacă se iau în considerare numai ,,potenţialii” arbori de viitor din SP1 și SP2, se constată și aici influența desimilor și densităților mai reduse din SP2 asupra dinamicii celor două diametre medii, care au crescut sensibil mai mult în această suprafață de probă. În plus, ponderea PADV din SP2 cu creșteri în diametru de minim $10 \mathrm{~cm}$ între 2009 și 2020 este de 80\%, comparativ cu doar 33,33\% în SP1 (tabelul 5).

Coeficienții de variaţie a diametrelor arborilor din cele trei situații considerate au evoluat în mod diferit: au crescut în SP1 şi SP2, până la valori în jur de $20 \pm 3 \%$, în timp ce diametrele celor 60 PADV au tins să se uniformizeze, coeficientul lor de variaţie reducându-se de la 14,89\% în 2009 la 11,81\% în 2020 (tabelul 6).

Între 2009 și 2020, înălţimea medie aritmetică $\hbar$ a crescut cu valori importante, însă foarte asemănătoare în valoare absolută, oscilând de la 8,21 m la cei 60 PADV la 8,62 m în SP1, adică o creștere, exprimată în valori relative, de la $118,47 \%$ (PADV) la

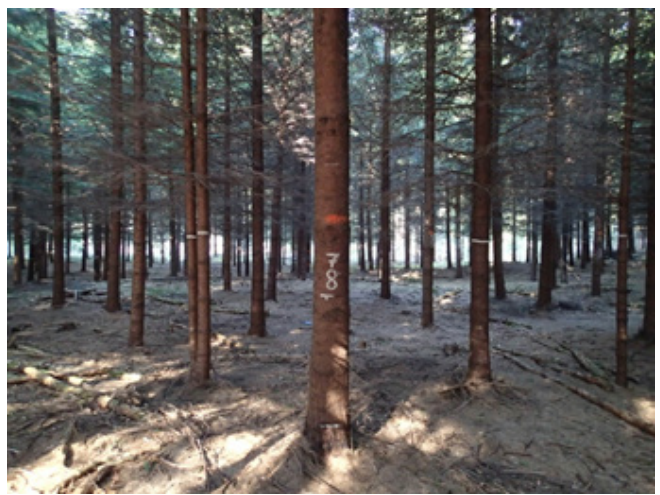

Figura 3 Arborele cel mai gros (nr. 78 din SP2, diametrul actual de $28,2 \mathrm{~cm})$, cu creșterea maximă în diametru $(16,4 \mathrm{~cm})$ între 2009 și 2020

The thickest tree (no. 78 in plot 2, current d.b.h. $28.2 \mathrm{~cm}$ ), with the maximum d.b.h. increment $(16.4 \mathrm{~cm})$ between 2009 and 2020

Tahel 4 Dinamica diametrului mediu al suprafeței de bază $\left(d_{g}\right)$ la arborii din SP1 și SP2 și la ,potențialii" arbori de viitor

Dynamics of quadratic mean diameter ( $\left.d_{g}\right)$ of trees in plots 1 and 2 and of "potential" final crop trees

Diametrul mediu al suprafeței de bază în... (cm)

\begin{tabular}{|c|c|c|c|c|c|c|}
\hline \multirow[t]{2}{*}{$\begin{array}{l}\text { SP } \\
\text { nr. }\end{array}$} & \multirow[t]{2}{*}{$\begin{array}{r}09.04 \\
2009\end{array}$} & \multirow[t]{2}{*}{$\begin{array}{c}04.07 . \\
2013 \\
\text { înainte }\end{array}$} & \multirow[t]{2}{*}{$\begin{array}{l}04.07 \\
2013 \\
\text { după }\end{array}$} & \multirow[t]{2}{*}{$\begin{array}{c}13.03 . \\
2020\end{array}$} & \multicolumn{2}{|c|}{$\begin{array}{c}\text { Creșterea lui } \\
\text { d }_{\mathrm{g}} \text { intre } 2009 \text { și } \\
2020\end{array}$} \\
\hline & & & & & (cn & $(0)$ \\
\hline 1 & 9,29 & & & & 8,75 & 94 \\
\hline 2 & 9,46 & 14 & 14 & 20 , & 10,75 & 113 \\
\hline DV & 9,67 & 14,80 & 14 & 20,78 & 11,11 & 114,8 \\
\hline
\end{tabular}

Tahel 5 Dinamica diametrului mediu aritmetic (đ) și a diametrului mediu al suprafeței de bază (d $\mathrm{g}_{\mathrm{g}}$ la ,„potențialii” arbori de viitor din SP1 și SP2

Dynamics of arithmetic mean diameter (d) and quadratic mean diameter ( $d_{g}$ ) of "potential" final crop trees in plots 1 and 2

\begin{tabular}{|c|c|c|c|c|c|c|c|c|c|}
\hline \multirow{3}{*}{$\begin{array}{l}\text { SP } \\
\mathrm{nr}\end{array}$} & \multicolumn{4}{|c|}{$\begin{array}{l}\text { Diametrul mediu aritmetic đîn ... } \\
\qquad(\mathrm{cm})\end{array}$} & \multicolumn{4}{|c|}{$\begin{array}{l}\text { Diametrul mediu al suprafeței de } \\
\text { bază } \mathrm{d}_{\mathrm{g}} \hat{\mathrm{in}} \ldots(\mathrm{cm})\end{array}$} & \multirow{3}{*}{$\begin{array}{l}\text { Ponderea PADV cu } \\
\text { creșteri în diametru } \\
\text { de minim } 10 \mathrm{~cm} \\
\text { între } 2009 \text { și } 2020 \\
(\%)\end{array}$} \\
\hline & \multirow{2}{*}{$\begin{array}{c}09.04 . \\
2009\end{array}$} & \multirow{2}{*}{$\begin{array}{c}13.03 . \\
2020\end{array}$} & \multicolumn{2}{|c|}{$\begin{array}{l}\text { Creșterea lui đ între } \\
2009 \text { și } 2020\end{array}$} & \multirow{2}{*}{$\begin{array}{l}09.04 \\
2009\end{array}$} & \multirow{2}{*}{$\begin{array}{c}13.03 \\
2020\end{array}$} & \multicolumn{2}{|c|}{$\begin{array}{c}\text { Creșterea lui dg } \\
\text { între } 2009 \text { și } 2020\end{array}$} & \\
\hline & & & c & $\%$ & & & $\mathrm{~cm}$ & 0 & \\
\hline 1 & 10,2 & 20,31 & 10 & 0,20 & 10,26 & דנה & 10 & 98,26 & \\
\hline 2 & 10,46 & 22,96 & 12,50 & 119,50 & 10,52 & 23,15 & 12,63 & 120,06 & 80,00 \\
\hline
\end{tabular}


Tahel 6 Coeficienții de variație a diametrelor arborilor din SP1 şi SP2, respectiv a diametrelor PADV, între 2009 şi 2020

Coefficients of variation of tree diameters in plots 1 and 2 as well as "potential" final crop trees between 2009 and 2020

\begin{tabular}{ccccc}
\hline \multicolumn{5}{c}{ Coeficienții de variație a diametrelor în... } \\
SP & \multicolumn{5}{c}{ (\%) } \\
\cline { 2 - 5 } nr. & 09.04. & 04.07. & 04.07. & 13.03. \\
& 2009 & $\begin{array}{c}2013 \\
\text { innainte }\end{array}$ & $\begin{array}{c}2013 \\
\text { după }\end{array}$ & 2020 \\
\hline 1 & 16,09 & 13,49 & 13,66 & 18,04 \\
2 & 16,34 & 18,66 & 19,71 & 23,55 \\
PADV & 14,89 & 13,58 & 13,58 & 11,81 \\
\hline
\end{tabular}

Tahel 7 Dinamica înălţimii medii aritmetice (h) la arborii din SP1 și SP2 și la ,potențialii” arbori de viitor

Dynamics of arithmetic mean height ( $\hbar)$ of trees in plots 1 and 2 and of "potential" final crop trees

\begin{tabular}{|c|c|c|c|c|c|c|}
\hline \multirow{3}{*}{$\begin{array}{l}\text { SP } \\
\text { nr. }\end{array}$} & \multicolumn{6}{|c|}{ Înălțimea medie aritmetică (h) în... (m) } \\
\hline & \multirow[t]{2}{*}{$\begin{array}{c}09.04 \\
2009\end{array}$} & \multirow[t]{2}{*}{$\begin{array}{c}04.07 . \\
2013 \\
\text { înainte }\end{array}$} & \multirow[t]{2}{*}{$\begin{array}{c}04.07 . \\
2013 \\
\text { după }\end{array}$} & \multirow[t]{2}{*}{$\begin{array}{c}13.03 . \\
2020\end{array}$} & \multicolumn{2}{|c|}{$\begin{array}{l}\text { Creșterea lui } \\
\text { † între } 2009 \text { şi } \\
2020\end{array}$} \\
\hline & & & & & $\mathrm{m}$ & $\%$ \\
\hline 1 & 6,51 & 10,74 & 10,88 & 15,13 & 8,62 & 132,41 \\
\hline 2 & 6,72 & 10,21 & 10,23 & 15,25 & 8,53 & 126,93 \\
\hline PADV & 6,93 & 10,87 & 10,87 & 15,14 & 8,21 & 118,47 \\
\hline
\end{tabular}

Tahel 8 Dinamica înălțimii corespunzătoare diametrului mediu al suprafeței de bază (h) la arborii din SP1 și SP2 și la ,potențialii” arbori de viitor

Dynamics of height corresponding to the quadratic mean diameter $\left(\mathrm{h}_{\mathrm{g}}\right)$ of trees in plots 1 and 2 and of "potential" final crop trees

\begin{tabular}{ccccccc}
\hline \multirow{2}{*}{$\begin{array}{c}\text { SP } \\
\text { nr. }\end{array}$} & \multicolumn{5}{c}{ Inălțimea corespunzătoare diametrului mediu al suprafeței de bază $\left(h_{g}\right)$ în... $(\mathrm{m})$} \\
\cline { 2 - 7 } & 09.04. & 04.07 .2013 & 04.07 .2013 & 13.03. & Creșterea lui $h_{g}$ între 2009 și 2020 \\
\hline 1 & 2009 & înainte & după & 2020 & m & $\%$ \\
\hline 2 & 6,69 & 10,85 & 10,94 & 15,18 & 8,49 & 126,91 \\
PADV & 7,01 & 10,34 & 10,39 & 15,14 & 8,31 & 121,67 \\
\hline
\end{tabular}

$132,41 \%$ (SP1), ceea ce presupune cel puțin dublarea valorilor inițiale din anul 2009 (tabelul 7).

Situarea arboretului într-o stațiune favorabilă, de bonitate superioară, a permis realizarea unor înălțimi medii aritmetice de peste $15 \mathrm{~m}$ în cele trei situații analizate, ceea ce reprezintă o creștere medie în înălțime la vârsta de 19 ani de cca $80 \mathrm{~cm} / \mathrm{an}$.

Și creșterea înălțimii corespunzătoare diametrului mediu al suprafeței de bază $h_{g}$ prezintă o dinamică similară, cu măriri ale acesteia, în valoare absolută, de peste $8 \mathrm{~m}$, respectiv de peste $115 \%$ în exprimare relativă (tabelul 8).

La arborii din cele două SP, precum și la PADV, s-au calculat valorile indicelui de zveltețe mediu $i_{z}$, ca raport între (a) înălţimea medie aritmetică (ち) şi diametrul mediu aritmetic (đ), respectiv între (b) înălțimea corespunzătoare diametrului mediu al suprafeței de bază $\left(\mathrm{h}_{\mathrm{g}}\right)$ și acest diametru mediu $\left(\mathrm{d}_{\mathrm{g}}\right)$. Ambele valori (înălțime și diametru) sunt exprimate în $\mathrm{cm}$ (tabelele 9a și 9b).

În cazul (a), pornind de la valori similare în anul 2009, coeficientul de zveltețe a crescut în $2020 \mathrm{cu}$ una $(1,39 \%)$, respectiv cinci $(6,94 \%)$ unități, în cazul PADV și în SP2, păstrându-se însă sub nivelul maxim (80) care definește un arboret stabil la acțiunea zăpezii sau vântului. În SP1, zveltețea s-a mărit cu 15 unităţi $(21,42 \%)$ și a atins nivelul 85, depășind plafonul menţionat.

O situație similară s-a constatat în cazul (b): coeficientul de zveltețe mediu inițial a fost de 72 în toate cele trei situații, crescând la arborii din SP2 şi PADV între 2009 și $2020 \mathrm{cu}$ doar una $(1,39 \%)$, respectiv trei $(4,17 \%)$ unități, păstrându-se sub nivelul maxim de 80 . În cazul 
Tahel 9 Dinamica indicelui de zveltețe mediu $\left[\mathrm{i}_{\mathrm{z}}=\right.$ $\hbar /$ d (a), respectiv $\left.i_{z}=h_{g} / d_{g}(b)\right]$ la arborii din SP1 și SP2 și la ,potențialii” arbori de viitor Dynamics of mean slenderness (stability) in$\operatorname{dex}\left[\left(S_{I}=\hbar / d\right.\right.$, (a) , and $S_{I}=h_{g} / d_{g}$, table (b) $]$ in trees of plots 1 and 2 and in "potential" final crop trees

a.

\begin{tabular}{|c|c|c|c|c|c|c|}
\hline \multirow{3}{*}{$\begin{array}{l}\text { SP } \\
\text { nr. }\end{array}$} & \multicolumn{6}{|c|}{ Indicele de zveltețe mediu (h/đ) în... } \\
\hline & \multirow{2}{*}{$\begin{array}{l}09.04 \\
2009\end{array}$} & \multirow{2}{*}{$\begin{array}{c}04.07 . \\
2013 \\
\text { înainte }\end{array}$} & \multirow{2}{*}{$\begin{array}{c}04.07 . \\
2013 \\
\text { după }\end{array}$} & \multirow{2}{*}{$\begin{array}{l}13.03 \\
2020\end{array}$} & \multicolumn{2}{|c|}{$\begin{array}{c}\text { Variația lui } i_{z} \\
\text { între } 2009 \text { și } \\
2020\end{array}$} \\
\hline & & & & & $\begin{array}{l}\text { Valori } \\
\text { absolute } \\
(+ \text { sau -) }\end{array}$ & $\%$ \\
\hline 1 & 70 & 81 & 81 & 85 & +15 & $+21,43$ \\
\hline 2 & 72 & 71 & 71 & 77 & +5 & $+6,94$ \\
\hline PADV & 72 & 74 & 74 & 73 & +1 & $+1,39$ \\
\hline
\end{tabular}

b.

\begin{tabular}{|c|c|c|c|c|c|c|}
\hline \multirow{3}{*}{$\begin{array}{l}\text { SP } \\
\text { nr. }\end{array}$} & \multicolumn{6}{|c|}{ Indicele de zveltețe mediu $\left(h_{g} / d_{g}\right)$ în... } \\
\hline & \multirow{2}{*}{$\begin{array}{l}09.04 \\
2009\end{array}$} & \multirow{2}{*}{$\begin{array}{c}04.07 . \\
2013 \\
\text { înainte }\end{array}$} & \multirow{2}{*}{$\begin{array}{c}04.07 . \\
2013 \\
\text { după }\end{array}$} & \multirow{2}{*}{$\begin{array}{l}13.03 \\
2020\end{array}$} & \multicolumn{2}{|c|}{$\begin{array}{l}\text { Variația lui } \mathrm{i}_{z} \\
\text { între } 2009 \text { și } \\
2020\end{array}$} \\
\hline & & & & & $\begin{array}{l}\text { Valori } \\
\text { absolute } \\
(+ \text { sau -) }\end{array}$ & $\%$ \\
\hline 1 & 72 & 80 & 80 & 84 & +12 & $+16,67$ \\
\hline 2 & 72 & 71 & 70 & 75 & +3 & $+4,17$ \\
\hline $\mathrm{ADV}$ & 72 & 74 & 74 & 73 & +1 & $+1,39$ \\
\hline
\end{tabular}

SP1, zveltețea s-a mărit cu 12 unități (16,67\%), iar valoarea sa din 2020 a depășit cu patru unităţi nivelul de 80, arboretul pătrunzând într-o zonă de stabilitate mai redusă.

Studiul legăturii dintre diametrul de bază inițial în anul 2009 și creșterea acestuia în perioada 2009-2020 (figura 4a-c) indică două aspecte interesante:

(i) Prezintă coeficienți de corelație R între cei doi parametri de 0,29 (PADV), 0,39 (SP1) și 0,70 (SP2), care indică o legătură slabă între cei doi parametri în SP1 și în cazul PADV, respectiv una puternică în SP2.

(ii) Coeficienții de variație a creșterii în diametru la arborii individuali din cele trei situații
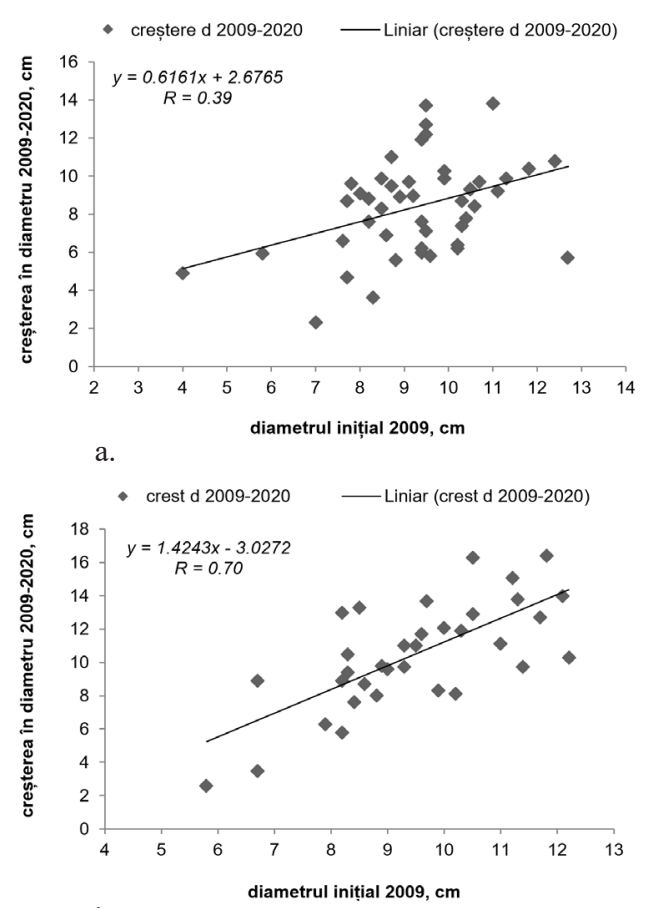

b.

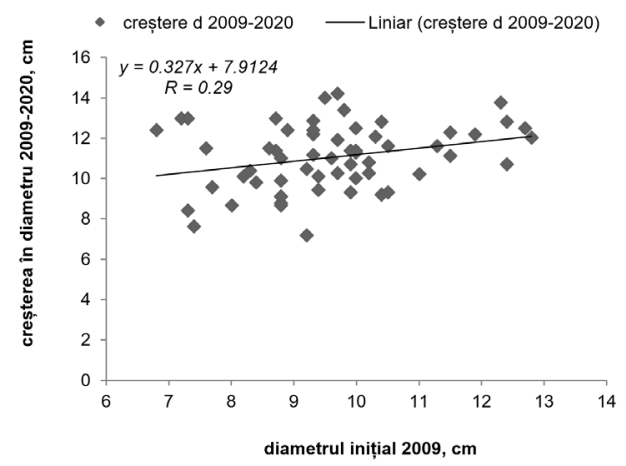

c.

Figura 4 Corelația dintre diametrul inițial al arborilor în anul 2009 și creșterea în diametru între 2009 și 2020 la arborii din SP1 (a) şi SP2 (b), precum şi la PADV (c)

Correlation between the initial d.b.h. (2009) and d.b.h. increment of trees in plots 1 (a) and 2 (b) as well as of "potential" final crop trees (c) between 2009 and 2020

comparate sunt ridicați şi apropiaţi de 30\% în SP1 $(29,79 \%)$ şi în SP2 (30,35\%), în timp ce la PADV valoarea acestui coeficient este mult redusă (creșterile în diametru sunt mult mai gru- 
pate în jurul mediei), reprezentând mai puțin de jumătate din valorile realizate în SP1 și SP2.

Un alt aspect biometric important, cu implicaţii asupra creșterii și producției arborilor individuali, este corelaţia dintre diametrul de bază și diametrul mediu al coroanei. În acest scop, au fost utilizate datele de la inventarierile din anul 2018, ultimul în care a fost posibilă măsurarea celor patru raze, dispuse în unghi de $90^{\circ}$, ale coroanelor arborilor (masivul s-a închis complet ulterior). Rezultatele obținute indică legătura strânsă între cei doi parametri, cu valori ale coeficienților de corelație $\mathrm{R}$ de 0,62 (PADV), 0,73 (SP1) și 0,88 (SP2) (figura 5a-c).

Pentru arborii cu diametrul de bază de 20 cm, diametrul mediu al coroanei variază de la $362 \mathrm{~cm}$ (SP1) la $399 \mathrm{~cm}$ (SP2), respectiv 406 cm (,potențiali” arbori de viitor). Diametrul mediu al coroanei la toți arborii măsuraţi în cele trei situații, indiferent de diametrul lor de bază $\left(\mathrm{d}_{1,30}\right)$, este $321 \mathrm{~cm}$ în SP1 (variaţie 200$450 \mathrm{~cm}$, coeficient de variație a diametrului mediu al coroanei 106,04\%), 376 cm în SP2 (de la 190 la $490 \mathrm{~cm}$, coeficient de variație 142,14\%), respectiv $394 \mathrm{~cm}$ la ,ppotențialii” "arbori de viitor (variație 285-465 cm, coeficient de variaţie $86,26 \%$ ).

Suprafața de bază a arboretului din SP1 şi SP2 a evoluat de la valorile amintite în tabelele 1 şi 2 la unele foarte ridicate, care depășesc $35 \mathrm{~m}^{2}$ ha $^{-1}$ în ambele SP în anul curent. În mod evident, creșterea suprafeței de bază, în valoare absolută și relativă, în intervalul cel mai sugestiv (2013-2020), a fost mai accentuată în SP2, care a prezentat cele mai mici desimi și densități în anul 2013, după lucrarea de rărituri, și în care arborii individuali au realizat cele mai mari creșteri în diametru (tabelul 10).

\section{Discuții}

Lucrările de curăţiri (2009) și rărituri (2013), cu caracter dominant combinat și aplicate preponderent cu intensităţi mari - puternice și foarte puternice - în cele două SP și la nivel de
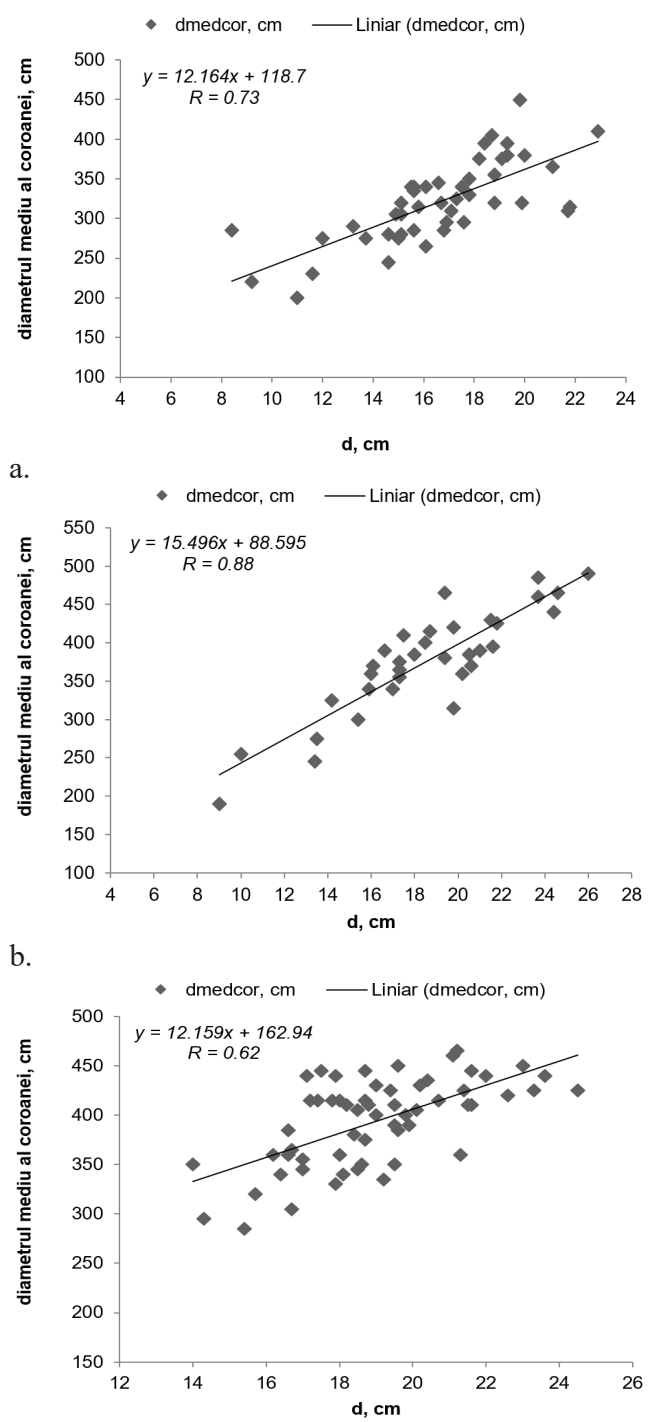

c.igura 5 Corelația dintre diametrul de bază și diametrul mediu al coroanei la arborii de molid din SP1 (a), SP2 (b) și , potențialii”” arbori de viitor (c) în anul 2018

Correlation between d.b.h. and mean crown diameter of Norway spruce trees in plots 1 (a), 2 (b) as well as "potential" final crop trees (c) in 2018

arboret, au condus la desimi reduse, de maxi-

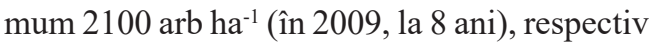

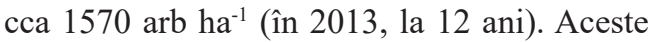
desimi, caracteristice plantațiilor din alte țări 
Tahel 10 Dinamica suprafeței de bază (G) în SP1 și SP2 între 2009 și 2020

Dynamics of basal area $(G)$ in plots 1 and 2 between 2009 and 2020

\begin{tabular}{|c|c|c|c|c|c|c|c|c|c|c|}
\hline \multirow{3}{*}{ SP nr. } & \multicolumn{10}{|c|}{ Suprafața de bază $(\mathrm{G})$ în... $\left(\mathrm{m}^{2} \mathrm{ha}^{-1}\right)$} \\
\hline & \multirow{2}{*}{$\begin{array}{c}09.03 . \\
2009 \\
\text { după }\end{array}$} & \multirow{2}{*}{$\begin{array}{c}04.07 . \\
2013 \\
\text { înainte }\end{array}$} & \multirow{2}{*}{$\begin{array}{c}04.07 . \\
2013 \\
\text { după }\end{array}$} & \multirow{2}{*}{$\begin{array}{c}13.03 \\
2020\end{array}$} & \multicolumn{2}{|c|}{$\begin{array}{c}\text { Creștere G } \\
\text { 2009-2013 înainte }\end{array}$} & \multicolumn{2}{|c|}{$\begin{array}{c}\text { Creștere G } \\
2013 \text { după-2020 }\end{array}$} & \multicolumn{2}{|c|}{$\begin{array}{c}\text { Creștere G totală } \\
2013-2020\end{array}$} \\
\hline & & & & & $\mathrm{m}^{2} \mathrm{ha}^{-1}$ & $\%$ & $\mathrm{~m}^{2} \mathrm{ha}^{-1}$ & $\%$ & $\mathrm{~m}^{2} \mathrm{ha}^{-1}$ & $\%$ \\
\hline 1 & 14,24 & 29,04 & 23,47 & 39,21 & 14,80 & 103,93 & 15,74 & 67,06 & 30,54 & 170,99 \\
\hline 2 & 9,85 & 23,56 & 20,36 & 37,44 & 13,71 & 139,19 & 17,08 & 83,89 & 30,79 & 223,08 \\
\hline
\end{tabular}

europene în momentul instalării, sunt mult mai mici decât cele recomandate în arboretele de la noi și care, în condiții ecologice similare (staţiuni de bonitate superioară, cu arborete din clasele de producție I și a II-a) și plantații cu desimea inițială de 6000-4000 puieți ha-1 ${ }^{-1}$, se recomandă să aibă 2850-3350 exemplare ha-1 (la 10 ani), respectiv 2500-3000 exemplare ha- ${ }^{-1}$ la 15 ani (Vlad și Petrescu 1977, Anonymous 2000b).

Desimile mici, rămase după cele două reprize de lucrări, au favorizat creșterile în diametru ale arborilor individuali din SP1 și SP2, care au condus la mărirea consistentă a valorilor diametrului mediu aritmetic și a diametrului mediu al suprafeței de bază. Acesta din urmă este un parametru folosit frecvent în Biometrie în scop auxologic pentru a defini ,,arborele mediu al arboretului”, mai mult decât diametrul mediu aritmetic (Giurgiu 1979, Pardé și Bouchon 1988, West 2004). Cum era de așteptat, creșterea valorii celor două diametre medii a fost mai importantă în SP2, care a prezentat valorile minime ale desimii și densității arboretului după lucrările aplicate. Acest efect, de ,accelerare a creșterii în diametru”, este specific intervențiilor (curățiri și rărituri) timpurii şi cu intensitate mare, ceea ce conduce la sporuri importante în volum, însă cu formarea lemnului cu inele late și densităţi mai reduse (Vlad și Petrescu 1977, Giurgiu 1979, Krajnc et al. 2019). Respectivele intervenții oferă însă avantajul formării unor arbori cu o zveltețe mai redusă, cu rezistență sporită la acțiunea dăunătoare a zăpezii și vântului (Haralamb 1967, Giurgiu 1979).

Un efect similar asupra creșterilor 1-a avut intervenția concentrată în jurul ,,potenţialilor” arbori de viitor, prin care li s-a favorizat mărirea dimensiunilor coroanei, cu efecte pozitive asupra creșterii în grosime.

Procedând în acest mod, s-a ajuns la situația ca, atât majoritatea arborilor din SP2, cât și „potențialii" arbori de viitor, distribuiți relativ uniform în cuprinsul arboretului, să crească în diametru în jur de $1 \mathrm{~cm} \mathrm{an}^{-1}$, atingând diametre de bază de $20 \mathrm{~cm}$ și peste la vârsta de 20 de ani. Prin efectele pozitive asupra diametrelor de bază, ca și asupra dimensiunilor (diametrelor) coroanei, considerăm că alegerea și favorizarea timpurie a „potențialilor” arbori de viitor de molid, încă de la finalul fazei de prăjiniş, pe baza criteriilor descrise în lucrarea noastră, așa cum se recomandă în diverse țări europene (Belgia: Wouters et al. 2000, Baar et al. 2004; Franţa: Allegrini 2010), este o opţiune de luat în seamă și la noi. Este evident că, din rațiuni legate de posibilitatea ca o parte dintre acești arbori să dispară până la exploatabilitate (răniți la exploatare, uscaţi datorită insectelor defoliatoare sau gândacilor de scoarță, vătămați de cervide sau de urs, aşa cum s-a întâmplat pe scară redusă și în arboretul de la Timișul de Sus), numărul lor să fie mai mare - de până la două ori - decât cel urmărit să existe în arboret la vârsta exploatabilității.

Însemnarea timpurie a acestor exemplare cu puncte sau inele evidente de vopsea asigură urmărirea lor cu continuitate de către cei care realizează punerea în valoare a masei lemnoase, favorizându-le și protejarea în cursul lucrărilor de exploatare (doborât și scos-apropiat).

Dacă, la noi, numărul de arbori de viitor recomandat prin normele tehnice în vigoare 
(Anonymous 2000b) este de 400-600 exemplare $\mathrm{ha}^{-1}$, cel recomandat în spaţiul forestier european (Germania: Abetz 1993; Belgia: Wouters et al. 2000, Baar et al. 2004, Perin 2016; Franța: Bastien 2001, Allegrini 2010) în situații similare este de 220-280 (300) arb $\mathrm{ha}^{-1}$. Această desime este considerată o alternativă eficace pentru gospodărirea molidișurilor pure, în contextul tendinței evidente pe plan european de reducere a vârstei exploatabilității acestora până la maximum 70-80 de ani, de mărire a stabilității arboretelor la acțiunea factorilor perturbatori (zăpadă, vânt) și adaptării lor la schimbările climatice preconizate, care necesită reducerea competiției pentru resursele supra- și subterane (Legay și Mortier 2006).

Arborii studiaţi, situaţi într-o stațiune de bonitate superioară pentru molid, au prezentat şi creșteri importante ale înălțimii (fie media aritmetică, fie cea corespunzătoare diametrului mediu al suprafeței de bază), care este însă mai mult influențată de potențialul staţiunii decât de intervențiile silvotehnice, spre deosebire de creșterea în diametru (Giurgiu 1979).

Înălțimea, în forma menționată, a atins valori de peste $15 \mathrm{~m}$, cu o creștere medie anuală de cca $80 \mathrm{~cm}$. Această valoare înscrie arboretul de molid (în areal natural) în clasa de producție relativă I, unde $h_{g}$ la vârsta de 20 de ani este de 9,2 m (Giurgiu și Drăghiciu 2004). Înălţimea de 15 m depăşește și valoarea lui $h_{g}$ la clasa de producție relativă I a arboretelor de molid în afara arealului, care este de 12,2 m (Giurgiu și Drăghiciu 2004).

Lucrările silvotehnice cu intensități mai mari din SP2, ca și asupra PADV, prin care creșterea în diametru a depășit-o pe cea în înălțime, au contribuit la mărirea indicelui de zveltețe cu 1-5 unităţi, care după 11 ani de la începerea lucrărilor se păstrează la un nivel inferior valorii de 80 în cele două situații. Prin comparație, creșterea zvelteții în SP1 a fost mult mai consistentă (12, respectiv 15 unităţi), conducând la valori de 84 și 85 în anul curent, deci arboretul de aici prezintă o stabilitate mai redusă la zăpadă/vânt.

Cercetările au reliefat și legătura dintre di18 ametrul inițial (2009) al arborilor și creșterea diametrului între 2009 și 2020, sub forma unei drepte de regresie, așa cum constata și Giurgiu (1967, 1979). Valoarea coeficientului de corelație în SP1, SP2 și la PADV variază între 0,29 și 0,70 , comparativ cu 0,4-0,9 în Giurgiu (1967, 1979).

Lucrările realizate în arboretul studiat au reliefat legătura strânsă dintre diametrul de bază și diametrul mediu al coroanei arborilor de molid, aceștia prezentând diametre de bază mari ca efect al unor coroane mari, obținute prin deschiderea puternică a coronamentului după lucrările de îngrijire și conducere. Respectiva legătură, pozitivă și liniară, a prezentat coeficienți de corelație între 0,62 şi 0,88 , valori apropiate de cele amintite în literatura de specialitate (0,75-0,85 - Giurgiu 1967, 1979). Acest fapt are implicații importante atât la alegerea exemplarelor de viitor, cât și la conducerea arboretelor tinere și de vârste mijlocii, în care se recomandă aplicarea de intervenții puternice și predominant de sus, cu același scop al reducerii competiției supra- și subterane.

Un ultim aspect demn de menţionat este creșterea puternică a suprafeței de bază în SP1 și SP2 la valori ridicate, de peste $35 \mathrm{~m}^{2} \mathrm{ha}^{-1}$ la doar 20 de ani. În conformitate cu tabelele de producție românești în vigoare (Giurgiu şi Drăghiciu 2004), suprafața de bază într-un „molidiș echien, pur și de densitate normală, parcurs cu operațiuni culturale de intensitate moderată", cu vârsta de 20 de ani, din clasa de producție relativă I, este de $29,2 \mathrm{~m}^{2} \mathrm{ha}^{-1}$. Diferența în plus de suprafață de bază în SP1 și SP2, care conduce la un indice de densitate de 1,34 (SP1), respectiv de 1,28 (SP2), obligă la aplicarea urgentă, pe parcursul anului 2020, a unei noi lucrări de rărituri, chiar ușor întârziată. Prin aplicarea sa, este posibilă reducerea indicelui de densitate la valori apropiate de cea unitară și apropierea suprafeței de bază la nivelul de maximum $30 \mathrm{~m}^{2} \mathrm{ha}^{-1}$, considerat valoare-plafon (suprafață de bază critică), în țări ca Belgia (Hébert et al. 2002) și Franța (Bastien 2000), pentru a preîntâmpina reducerea semnificativă a producției volumetrice a arboretului. 


\section{Concluzii}

Lucrarea noastră s-a dorit să ofere un exemplu simplu de silvotehnică a molidișurilor artificiale, pure și tinere, altfel decât cel „tradițional" și recomandat în mod uzual în România. Prin acesta, s-a demonstrat, pe scară redusă și în condiții staționale favorabile că, folosind modalități și soluții silvotehnice ușor de aplicat la scară de producție, există posibilitatea amplificării creșterilor radiale și obținerii de sortimente de molid cu utilizare industrială (cherestea, plăci, chiar celuloză) la vârste mai mici decât cele obișnuite în condițiile noastre de cultură. Așa cum sublinia Giurgiu încă din anul 1967, „Se știe de pe acum că răriturile de intensitate ridicată accelerează procesul de creștere la arborii rămași și prin aceasta contribuie la reducerea vârstelor exploatabilității absolute și tehnice".

Pe baza celor prezentate, considerăm că este necesară aplecarea mult mai atentă, de către autoritatea centrală care răspunde de silvicultura din România, asupra problematicii lucrărilor de îngrijire și conducere a arboretelor noastre, mai ales tinere și de vârste mijlocii. Fără luarea în considerare a nevoilor şi cerințelor pieței lemnului, a aspectelor economice implicate în silvotehnică (spre exemplu, costul puieților și al lucrărilor de instalare și întreținere a culturilor, mărirea constantă a cheltuielilor cu forța de muncă, în condițiile împuținării dramatice a efectivului acesteia pentru diverse lucrări silvice), a cerințelor și utilajelor specifice lucrărilor de exploatare a pădurilor, o silvotehnică de calitate și viabilă pe termen lung nu este posibilă. La acestea se adaugă și necesităţile adaptării pădurilor la schimbările climatice potențiale, care presupun o multitudine de solutiii, între care ,conducerea (arboretelor - n.n.) prin alegerea arborilor de viitor și realizarea răriturilor în jurul acestora" a fost recomandată recent și la noi (Barbu et al. 2016).

Șansa trecerii spre o silvicultură adaptativă şi dinamică există actualmente în România, în contextul derulării Proiectului SIPOCA 395, coordonat de către Ministerul Apelor și
Pădurilor, și prin care se vor realiza studii de fundamentare pentru elaborarea de diverse proceduri administrative simplificate specifice, respectiv ghiduri de bune practici (inclusiv pentru lucrări de îngrijire și conducere a arboretelor) și regulamente pentru silvicultură. Se dorește ca acestea să nu fie doar copy-paste după actualele norme tehnice și regulamente, ci să aducă modificări de substanță, necesare, chiar obligatorii, în problematica instalării culturilor, a lucrărilor de îngrijire și conducere a arboretelor, a tratamentelor, a lucrărilor de punere în valoare și, mai ales, a amenajării pădurilor.

\section{Mulțumiri}

Autorii mulțumesc și pe această cale colegilor din cadrul Regiei Publice Locale a Pădurilor Kronstadt (Brașov), fără a căror bunăvoință și colaborare de lungă durată nu ar fi fost posibilă realizarea lucrărilor și cercetărilor de teren.

Mulțumim și colegilor și prietenilor Krasimira Petkova (Bulgaria), Karoly Rédei (Ungaria), Torsten Vor (Germania), Marcin Klisz (Polonia), Nicola La Porta (Italia), Dejan Mandzukovski (Macedonia de Nord), Robert Brus (Slovenia), Branislav Cvjetkovic (Bosnia şi Herzegovina) şi Vasyl Lavnyy (Ucraina), pentru informațiile și bibliografia puse la dispoziție.

În aceeași măsură, mulțumim și referenților anonimi al lucrării.

\section{Bibliografie}

AFNOR, 1999. Classement qualititif des bois ronds résineux. Partie 1: Épicéas et sapins. Association Française de Normalisation, Paris, $7 \mathrm{p}$.

Anonymous, 2000a. Norme tehnice privind compoziţii, scheme şi tehnologii de regenerare a pădurilor şi de împădurire a terenurilor degradate 1. Ministerul Apelor, Pădurilor şi Protecţiei Mediului, Bucureşti, 272 p.

Anonymous, 2000b. Norme tehnice pentru îngrijirea şi conducerea arboretelor 2. Ministerul Apelor, Pădurilor şi Protecţiei Mediului, Bucureşti, 164 p.

Anonymous, 2000c. Norme tehnice pentru amenajarea 
pădurilor 5. Ministerul Apelor, Pădurilor şi Protecţiei Mediului, Bucureşti, 163 p.

Anonymous, 2009. Norway spruce (Picea abies (L.) Karst). National Development Plan, Department of the Marine and Natural Resources, Forest Service, Ireland, sheet 9, 2 p.

Abetz P., 1993. L'arbre d'avenir et son traitement sylvicole en Allemagne. Revue Forestière Française, XLV (5): 551-560. https://doi.org/10.4267/2042/26455

Allegrini Ch., 2010. Choisir les arbres d'avenir. Forêts de France, no. 531, mars: 33-34.

Baar F., Snoeck B., Balleux P., Claessens H., 2004. La sylviculture d'arbres "objectif" ou arbres de place. Forêt Wallonne, no. 68, janvier-février: 2-8.

Barbu I., 1982. Cercetări privind influenţa factorilor din sol şi a altor factori staţionali asupra rupturilor şi doborâturilor produse de zăpadă în pădurile din Bucovina. Rezumatul tezei de doctorat. Universitatea din Braşov, $30 \mathrm{p}$.

Barbu I., Curcă M., Barbu C., Ichim V., 2016. Adaptarea pădurilor României la schimbările climatice. Editura Silvică, Voluntari, 380 p.

Bary-Lenger A., Evrard R., Gathy P., 1988. La forêt. Ecologie-gestion-economie-conservation. Troisième edition. Editions du Perron, Liège, 619 p.

Bary-Lenger A., Pierson J., Poncelet J., 1999. Transformation, utilisation et industries du bois en Europe. Editions du Perron, Liège, $557 \mathrm{p}$.

Bastien Y., 1997. Sylviculture des essences résineuses. Ecole Nationale du Génie Rural, des Eaux et des Forêts, Centre de Nancy, $22 \mathrm{p}$.

Bastien Y., 2000. Sylviculture des essences résineuses. Ecole Nationale du Génie Rural, des Eaux et des Forêts, Centre de Nancy, 22 p.

Bastien Y., 2001. Arbres-objectif. Élagage artificiel. Ecole Nationale du Génie Rural, des Eaux et des Forêts, Centre de Nancy, $17 \mathrm{p}$.

Baylot J., Vautherin O., 1991. Classement des bois ronds résineux. CTBA, Paris, 94 p.

Becquey J., Riou-Nivert Ph., 1987. L'existance de "zones de stabilité" des peuplements. Conséquences sur la gestion. Revue Forestière Française, no. spécial "Les chablis": 323-334. https://doi.org/10.4267/2042/25804

Beldeanu E., 1999 Produse forestiere și studiul lemnului I. Editura Universității Transilvania, Brașov, 362 p.

Beldeanu EC., 2008. Produse forestiere. Editura Universității Transilvania din Brașov, Brașov, 331 p.

Borel W., 1929. Guide pour l'application du contrôle aux futaies jardinées. Imprimerie Jacques et Demontrond, Besançon, $104 \mathrm{p}$.

Caudullo G., Tinner W., de Rigo D., 2016. Picea abies in Europe: distribution, habitat, usage and threats. În: San-Miguel-Ayanz J., de Rigo D., Caudullo G., Houston Durrant T., Mauri A. (ed.). European Atlas of Forest Tree Species. Publication Office of the European Union, Luxembourg, pp. 114-116.

Changsheng L., Jianfeng S., Yongfang X., Colin F., Houllier F., 1998. Crown morphology of Norway spruce from usual tree measurements. Journal of Forestry Re- search 9 (1): 8-12. https://doi.org/10.1007/BF02856445

Cochet P., 1971. Étude et culture de la forêt. 3-ème édition. Ecole Nationale du Génie Rural, des Eaux et des Forêts, Nancy, $235 \mathrm{p}$.

Drăcea M., 1923. Silvicultură (note de curs). Școala Politehnică, București, 1024 p.

Duduman M.L., Lupaştean D., 2019. Conferința internațională "Semnificația schimbărilor actuale de mediu asupra dăunătorilor și patogenilor din ecosistemele forestiere", Suceava, 16-20 septembrie 2019. Bucovina forestieră, 19(2): 205-214. https://doi.org/10.4316/ bf.2019.026

Dumitriu-Tătăranu I., Ghelmeziu I., Florescu I.I., Milea I., Moș V., Tocan M., 1983. Estimarea calității lemnului prin metoda carotelor de sondaj. Editura Tehnică, București, 348 p.

Faure G., Pătrăucean A., Nicolescu V.N., 2015. Un exemple de la sylviculture de l'Epicea commun entre deux extrêmes. Revista pădurilor, nr. 5-6: 5-22.

Giurgiu V., 1967. Studiul creșterilor la arborete (Auxometrie cu elemente de auxologie). Editura Agro-Silvică, București, 322 p.

Giurgiu V., 1979. Dendrometrie și auxologie forestieră. Editura Ceres, București, 692 p.

Giurgiu V., Drăghiciu D., 2004. Modele matematico-auxologice și tabele de producție pentru arborete. Editura Ceres, București, 607 p.

Haralamb At., 1967. Cultura speciilor forestiere. Ediția a III-a. Editura Agro-Silvică, București, 755 p.

Hart C., 1994. Plantation forestry for the agent and surveyor. Alan Sutton, Stroud, 658 p.

Hébert J., Herman M., Jourez B., 2002. Sylviculture et qualité du bois de l'épicéa en région vallonne. asbl Forêt Vallonne, $157 \mathrm{p}$.

Horodnic S.A.., 1999. Cercetări privind structura arboretelor echiene de molid în raport cu densitatea lemnului. Rezumatul tezei de doctorat. Universitatea "Ștefan cel Mare", Suceava

Katrevičs J., Džeriņa B., Neimane U., Desaine I., Bigača Z., Jansons A., 2018. Production and profitability of low density Norway spruce (Picea abies (1) Karst.) plantation at 50 years of age: case study from eastern Latvia. Agronomy Research 1: 113-121.

Krajnc L., Farrelly N., Harte AM., 2019. The effect of thinning on mechanical properties of Douglas fir, Norway spruce, and Sitka spruce. Annals of Forest Science, 76(3): 1-12. https://doi.org/10.1007/s13595-0180787-6

Kramer H., 1980. Tending and stability of Norway spruce stands. În: Klimo, E (ed.). Stability of spruce forest ecosystems, International symposium, Faculty of Forestry, Brno, pp. 121-133.

Läänelaid A., Helama S., Bijak S., 2016. Assessments of diameter growth and optimal rotation length for evenaged spruce sites in Estonia. Baltic Forestry 2: 212-221.

Legay M., Mortier F., 2006. La forêt face au changement climatique. Adapter la gestion forestière. Les dossiers forestiers no. 16, juin, Office National des Forêts, INRA, Paris, $39 \mathrm{p}$. 
Marcu Gh., 1974. Stadiul cunoștințelor. În: Marcu Gh. (resp.coord.). Cercetări privind extinderea culturii molidului în R.S. România, Editura Ceres, București, pp. 15-42.

Marcu Gh., Ursulescu A., Ghelmeziu N., Rădulescu S., 1974. Caracteristicile fizico-mecanice ale lemnului, greutatea uscată și randamentul în celuloză al culturilor de molid în afara arealului în diferite tipuri fundamentale de păduri. În: Marcu Gh.(resp.coord.). Cercetări privind extinderea culturii molidului în R.S. România, Editura Ceres, București, pp. 351-378.

Mäkinen H., Hein S., 2006. Effect of wide spacing on increment and branch properties of young Norway spruce. European Journal of Forest Research, Vol. 125 (3): 239-248. https://doi.org/10.1007/s10342-006-0115-9

Orlić S., 1989. Rezultati o visinskom i debljinskom rastu obične smreke (P. abies Karst) u pokusima različitih razmaka sadnje na području Slavonije (The results of height and diameter growth of Norway spruce (P. abies Karst) in the experiments with different spacing of planting in Slavonia). Sumarski List, vol. 113 (1-2): 17-25 (rezumat în limba engleză).

Pain O., 1996. Sylviculture de l'Épicéa commun. ONF, Paris, Bulletin technique, 31: 43-51.

Pardé J., 1984. Production et sylviculture de L'Epicéa commun en plantations. Revue Forestière Française, XXXVI(4): 259-267. https://doi. org/10.4267/2042/21736

Pătrăucean A., Nicolescu V.N., 2011. Early silviculture of Norway spruce (Picea abies Karst.) between economics and stability: a case-study. Spanish Journal of Rural Development, II (2): 23-31. https://doi.org/10.5261/2011. GEN2.02

Pătrăucean A., 2012. "Stand silviculture" versus "crop tree silviculture" in young Norway spruce (Picea abies Karst.) stands: A case-study. Revista pădurilor, 127 (1): 43-50.

Perin J., 2016 Nouvelles normes sylvicoles pour les peuplements purs équiennes d'épicéa. Gembloux Agro-Bio Tech, Université de Liège, Service public de Wallonie, DGO3, $12 \mathrm{p}$.

Perrin H., 1954. Sylviculture. Tome II Le traitement des forêts. Ecole Nationale des Eaux et Forêts, Nancy, 411 p.

Petrescu L., Ciumac Gh., Mihalache V., 1962. Tehnica tăierilor de îngrijire în arboretele de molid. Editura Agro-Silvică, Bucureşti, 27 p.

Petrescu L., Ciumac Gh., Stoiculescu C., 1967. Cercetări privind metodele de curăţiri şi rărituri în molidişuri. Centrul de documentare tehnică pentru economia forestieră, Bucureşti, 79 p.

Petrescu L., Haring P., 1977. Periodicitatea şi intensitatea curăţirilor şi răriturilor în molidişuri şi pinete, în funcţie de condiţiile de exploatare și economice. Centrul de material didactic şi propagandă agricolă, Bucureşti, 47 p.

Pollini C., 2006. Manuale per la classificazione visuale qualitativa del legno tondo di abete rosso, abete bianco e larice. Provincia Autonoma di Trento-Servizio Foreste e Fauna, CNR-IVALSA, Trento, 112 p.

Pukall K., 2019. Douglas-fir discourse in Germany. În: Spiecker H., Lindner M., Schuler J. (ed.). Douglas-fir - an option for Europe. What science can tell us 9, European Forest Institute, Joensuu, pp. 111-116.

Riou-Nivert Ph., 1996. Les résineux. Tome I: Connaissance et reconnaisance. Institut pour le développement forestier, Paris, $256 \mathrm{p}$.

Saniga M., 2007. Struktura lasów przerebowych w wybranych regonach orograficznych Slowacji (Structura arboretelor grădinărite din anumite regiuni orografice ale Slovaciei). Sylwan 10: 54-66 (rezumat în limba engleză)

Savill P.S., 1983: Silviculture in windy climates. Forestry Abstracts, vol. 44(8): 473-488.

Savill P., Evans J., Auclair D., Falck J., 1997. Plantation silviculture in Europe. Oxford University Press, Oxford-New York-Tokyo, 297 p.

Scohy J-P. 1989. Peuplements résineux : éclaircie et élagage. Silva Belgica, vol. 96(1), pp. 7-52.

Szymańsky S., 2007. Silviculture of Norway spruce. În: Tjoelker M.G., Boratyński A., Bugała W. (ed.). Biology and Ecology of Norway Spruce, Springer, Dordrecht, pp. 295-307. https://doi.org/10.1007/978-1-4020-48418_13

Tisserand A., Pardé J., 1982. Le dispositif expérimental des Heez d'Hargnies (Ardennes) : contribution à la définition d'une sylviculture pour les plantations d'Epicéa commun dans le Nord-Est de la France. Revue Forestière Française, XXXIV (6): 353-379. https://doi. org/10.4267/2042/21617

Van Loo M., Dobrowolska D., 2019. Current situation. În: Spiecker H., Lindner M., Schuler J. (ed.). Douglas-fir - an option for Europe. What science can tell us 9, European Forest Institute, Joensuu, pp. 26-29.

Vlad I., Petrescu L., 1977. Cultura molidului în România. Editura Ceres, București, 359 p.

Weinfurter P., 2004. Waldbauhandbuch. Österreichische Bundesforte AG, Pinkersdorf, $110 \mathrm{p}$.

Wouters Ph. de, Notelaers V., Balleux P., 2000. Sélectionner les arbres d'avenir. Silva Belgica, 107 (1): I-VI.

Zeidler A., Borůvka V., 2018. Wood quality of Douglas-fir from the Czech Republic territory. În: Novák J., Kacálek D., Podrázský V., Šimerda 1. (coord.). Applying Douglas-fir in forest management of the Czech Republic. Lesnická Práce, s.r.o., pp. 186-205.

Zeltiņš P., 2017. Modeling growth of genetically improved Norway spruce. MSc thesis. Swedish University of Agricultural Sciences, Southern Swedish Forest Research Centre, Alnarp, $40 \mathrm{p}$. 